\title{
Cytotoxicity of Calcium Hydroxide on Human Umbilical Cord Mesenchymal Stem Cells
}

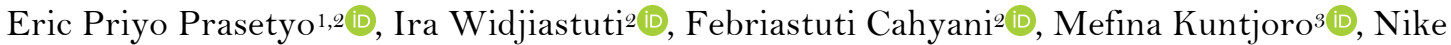

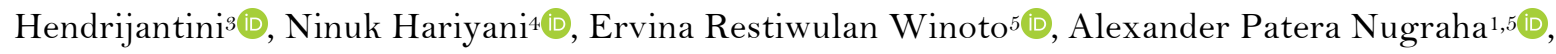

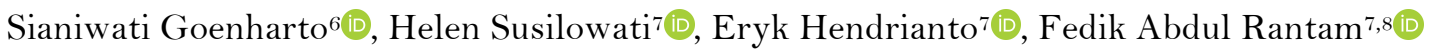

\footnotetext{
${ }^{1}$ Doctoral Program, Faculty of Medicine, Universitas Airlangga, Surabaya, Indonesia.

${ }^{2}$ Department of Conservative Dentistry, Faculty of Dental Medicine, Universitas Airlangga, Surabaya, Indonesia.

${ }^{3}$ Department of Prosthodontics, Faculty of Dental Medicine, Universitas Airlangga, Surabaya, Indonesia.

${ }^{4}$ Department of Dental Public Health, Faculty of Dental Medicine, Universitas Airlangga, Surabaya, Indonesia.

${ }^{5}$ Department of Orthodontics, Faculty of Dental Medicine, Universitas Airlangga, Surabaya, Indonesia.

${ }^{6}$ Department of Health, Faculty of Vocational Studies, Universitas Airlangga, Surabaya, Indonesia.

${ }^{7}$ Stem Cell Research and Development Center, Universitas Airlangga, Surabaya, Indonesia.

${ }^{8}$ Laboratory of Virology and Immunology, Department of Microbiology, Faculty of Veterinary Medicine, Universitas Airlangga, Surabaya, Indonesia.
}

Author to whom correspondence should be addressed: Eric Priyo Prasetyo, Department of Conservative Dentistry, Faculty of Dental Medicine, Universitas Airlangga, Jalan Mayjen Prof Dr. Moestopo 47, Surabaya, Indonesia. Phone: +62 315030255. E-mail: eric-p-p@fkg.unair.ac.id.

Academic Editor: Yuri Wanderley Cavalcanti

Received: 09 March 2020 / Accepted: 14 May 2020 / Published: 20 July 2020

How to cite this article: Prasetyo EP, Widjiastuti I, Cahyani F, Kuntjoro M, Hendrijantini N, Hariyani N, et al. Cytotoxicity of calcium hydroxide on human umbilical cord mesenchymal stem cells. Pesqui Bras Odontopediatria Clín Integr. 2020; 20:e0044. https://doi.org/10.1590/pboci.2020.141

\begin{abstract}
Objective: To examine the cytotoxicity of calcium hydroxide on human umbilical cord mesenchymal stem cells (HUCMSC) to understand the characteristics for use in regenerative dentistry procedures especially regenerative endodontics. Material and Methods: HUCMSC was isolated, cultured, and confirmed by flow cytometry. The biological characteristics, such as cell morphology, proliferation, and protein expression, were screened. To check the cytotoxicity, HUCMSC was cultured and divided into two groups, the control group (cultured in minimum essential medium (MEM) alpha) and calcium hydroxide group (cultured in MEM alpha and calcium hydroxide). Methyl-thiazole-tetrazolium (MTT) assay was done on different concentrations of calcium hydroxide (0.39 to $25 \mu \mathrm{g} / \mathrm{mL}$ ) and the cells were observed and counted. One-way ANOVA test was used with a significance level set at $5 \%$. Results: Flow cytometric analysis confirmed positive of $\mathrm{CD} 73$, CD90, CD105, negative of CD45 and CD34. A significant difference was found between the concentration of 6.25 and $3.125 \mu \mathrm{g} / \mathrm{mL}(\mathrm{p}=0.004)$. There was no significant difference among 6.25, 12.5 and $25 \mu \mathrm{g} / \mathrm{mL}$ concentrations. There was also no significant difference among $0.39,0.78,1.56$, and 3.125 $\mu \mathrm{g} / \mathrm{mL}$ concentrations. Conclusion: Even though calcium hydroxide is a medicament of choice in clinical endodontics, it decreases the viability of HUCMSC. The lower the concentration of calcium hydroxide, the higher the viability of HUCMSC.
\end{abstract}

Keywords: Dentistry; Stem Cell Research; Umbilical Cord; Cell Survival. 


\section{Introduction}

There are several mesenchymal stem cells (MSC) sources for clinical applications. Human umbilical cord mesenchymal stem cells (HUCMSCs) are MSC found in the umbilical cords and may be attractive candidates for tissue regeneration [1]. Compared to other sources of stem cells from adult tissues, HUCMSCs are more primitive, non-invasive procedure of collection, provide high proliferation potential, high differentiation potential, immune-privileged, immunosuppressive, rich in stemness [2]. Currently, HUCMSC is vastly studied to be used for regenerative, e.g., diabetes and its complications.

Calcium hydroxide $(\mathrm{CH})$, an odorless white powder, is a strong alkali or base [3]. It has long been used in various treatment modalities in conservative dentistry, including intracanal dressings, root canal sealers, and pulp-capping material [4]. Calcium hydroxide is an essential alkaline material used in protocols of a successful regenerative endodontic treatment regimen [5] and the material of choice of all pulp therapy [4]. Its high $\mathrm{pH}$ level determines the mineralizing action of calcium hydroxide, and the hydroxyl group is reckoned as the most important part as it gives an alkaline milieu, which promotes healing and mineralization [3].

The use of HUCMSC in dentistry is still limited and therefore needs to be explored. Many researches have examined the cytotoxicity of calcium hydroxide, but few studies have used HUCMSC. Cell cultures are generally done to evaluate the biocompatibility of many materials [6,7]. In vitro experiments of cell cultures are usually performed to explore mechanisms and biological responses in certain conditions. Even though results from in vitro experiments cannot immediately be deduced to human clinical conditions, they are clinically pertinent as they regard a model for screening of various material properties and risks [8]. HUCMSC was studied to the evaluate cytotoxicity of scaffold material for regenerative tissue engineering [9].

Stem cells' viability and response may differ depending on the time variation of contact from available calcium hydroxide. To further explore the potency of calcium hydroxide on HUCMSC, viability testing is important to be done. Therefore, the objective of this study was to investigate the cytotoxicity of calcium hydroxide on the viability of HUCMSC through MTT assay.

\section{Material and Methods}

Isolation, Expansion and Cultivation of HUCMSC

The isolation, expansion, and cultivation of HUCMSC are according to the protocol of Stem Cell Research and Development Center Universitas Airlangga [9]. Umbilical cord tissue from the donor was cleaned and washed from blood or debris with sterile Dulbecco's Phosphate Buffered Saline (Gibco, Thermo Fisher Scientific Inc., Waltham, MA USA), the Wharton's Jelly was taken and then finely cut. Collagenase Type 4 (Worthington Biochemical Corporation, Lakewood, NJ, USA) was added to collect stem cells from the umbilical tissue.

Incubation was done for 45 minutes at $37^{\circ} \mathrm{C}$. The cells and medium were centrifuged to form a pellet of cells. Minimum essential medium (MEM) alpha was added to the pellet and planted in a $100 \mathrm{~mm}$ tissue culture plate (Iwaki, Asahi, Japan) and incubated at $37^{\circ} \mathrm{C}$. The plate was checked daily until it forms $80-90 \%$ monolayer; the cells were split to form the next passage. Cells from the fourth passage were characterized at Stem Cell Research and Development Center Universitas Airlangga (Surabaya, Jawa Timur, Indonesia).

A total of $2 \times 10^{6}$ HUCMSC were taken for flow cytometric analysis. Flow cytometric analysis confirmed the positive of CD73, CD90, CD105, negative of CD45 and CD34. All antibodies were purchased from BD Biosciences. HUCMSC were analyzed using a FACS Calibur Becton-Dickinson (BD Biosciences, San Jose, CA, USA), and the data were analyzed using CellQuest software (BD Biosciences, San Jose, CA, USA). 


\section{Calcium Hydroxide Preparation for HUCMSC}

Calcium hydroxide medium was prepared by mixing the calcium hydroxide powder $\left(\mathrm{EMSURE}^{\circledR}\right.$, Merck KGaA, Darmstadt, Germany) with minimal essential medium (MEM) alpha (Gibco, Thermo Fisher Scientific Inc., Waltham, MA USA). We use calcium hydroxide concentration of 0.39, 0.78, 1.56, 3.125, 6.25, 12.5 , and $25 \mu \mathrm{g} / \mathrm{mL}$ to be compared in this experiment.

Viability of HUCMSC on Calcium Hydroxide

The viability of HUCMSCs on Calcium hydroxide was determined by methyl-thiazol-tetrazolium (MTT) assay [9]. The fifth passage HUCMSCs were seeded at a density of 5,000 cells per well in a 96-well microtiter plate (Iwaki, Asahi, Japan) and treated with calcium hydroxide at concentrations 0.39-25 $\mu \mathrm{g} / \mathrm{mL}$ for 24 hours. Each well was given 200 microliter medium containing calcium hydroxide according to the explored concentrations.

After incubation, MTT was added to each well and incubated for 3 hours; the addition of dimethyl sulfoxide stopped the process. Cell viability was analyzed by measuring the optical density (OD) detected by an automatic microplate reader (GloMax ${ }^{\circledR}$ Explorer, Promega Corporation, Madison, WI, USA) at a wavelength of $595 \mathrm{~nm}$. The assessment was done in triplicates.

\section{Statistical Analysis}

Data were provided as mean and standard deviation. Statistical analysis was performed using SPSS software (SPSS Inc., Chicago, IL, USA), version 20.0. All data were tested for normality. One-way ANOVA test was used for comparisons among control and different concentrations of calcium hydroxide groups.

Ethical Aspects

This study was approved by the Health Research Ethical Clearance Commission, Universitas Airlangga Faculty of Dental Medicine, Surabaya, Indonesia (Clearance number 059/HRECC.FODM/II/2020), and written informed consent was obtained before specimen collection.

\section{Results}

The presence of mesenchymal stem cells taken from human umbilical cord was established and identified through antibodies for CD105, CD90, CD73, CD45, and CD34. The flow cytometry recorded more than $95 \%$ positivity of $\mathrm{CD} 105$, CD90, CD73, negativity of $\mathrm{CD} 45$ and CD34. This result confirmed the characterized cells are HUCMSC.

Viable cells seen under an inverted microscope are available in Figure 1. The mean and standard deviation (SD) of control and calcium hydroxide groups are shown in Table 1. Data in the result was distributed normally $(\mathrm{p}>0.05)$, and homogeneity test yield homogeny data $(\mathrm{p}>0.05)$. The significance is shown in Table 2.

MTT assay result of different calcium hydroxide $(\mathrm{CH})$ concentrations showed no significant difference among 6.25, 12.5, and $25 \mu \mathrm{g} / \mathrm{mL}$. There was also no significant difference between $0.39,0.78,1.56$, and 3.125 $\mu \mathrm{g} / \mathrm{mL}$. The significant difference was found between 3.125 and $6.25 \mu \mathrm{g} / \mathrm{mL}(\mathrm{p}=0.004)$. 


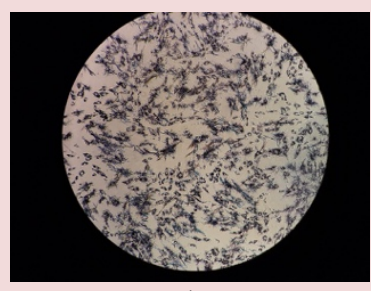

A

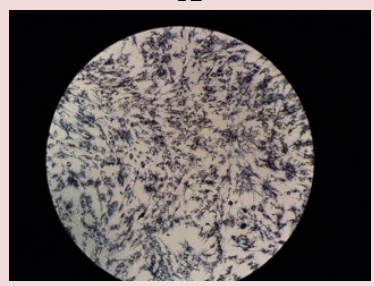

E

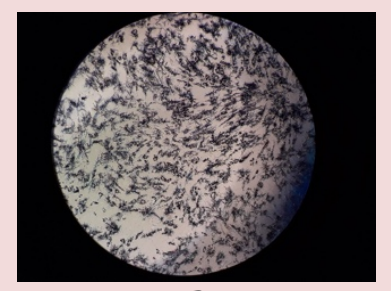

B

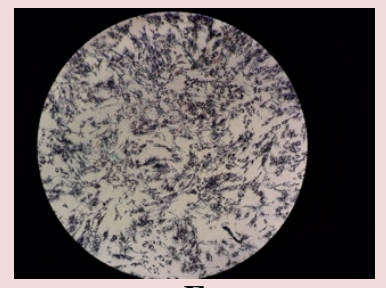

$\mathbf{F}$

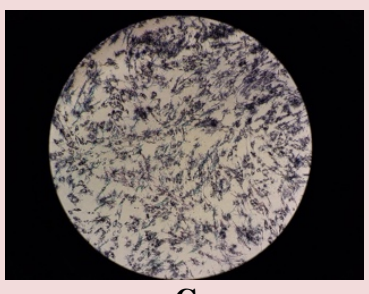

C

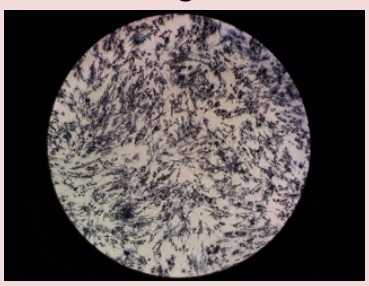

G

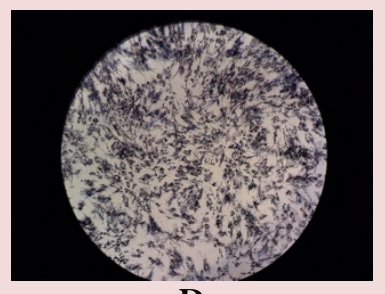

D

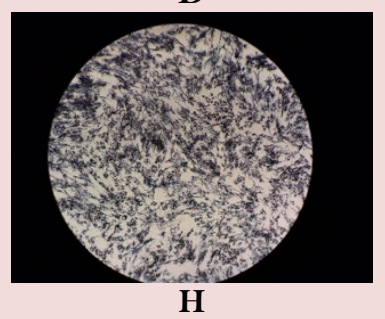

Figure 1. The viable cells seen with inverted microscope: control (A), CH concentration of $25 \mu \mathrm{g} / \mathrm{mL}$ (B), $12.5 \mu \mathrm{g} / \mathrm{mL}$ (C), $6.25 \mu \mathrm{g} / \mathrm{mL}$ (D), $3.125 \mu \mathrm{g} / \mathrm{mL}$ (E), $1.56 \mu \mathrm{g} / \mathrm{mL}$ (F), $0.78 \mu \mathrm{g} / \mathrm{mL}$ (G), and 0.39 $\mu \mathrm{g} / \mathrm{mL}(\mathbf{H})$.

Table 1. Mean and standard deviation of control and $\mathrm{CH}$ groups.

\begin{tabular}{lc}
\hline \multicolumn{1}{c}{ Groups } & $\begin{array}{c}\text { Cell Viability } \\
\text { Mean (SD) }\end{array}$ \\
\hline Control & $100 \pm 0.00$ \\
CH 25 & $56.1013 \pm 3.22481$ \\
CH 12.5 & $58.0903 \pm 6.76619$ \\
CH 6.25 & $58.4880 \pm 3.06637$ \\
CH 3.125 & $69.0950 \pm 2.50740$ \\
CH 1.56 & $69.8520 \pm 2.27282$ \\
CH 0.78 & $70.0930 \pm 3.26168$ \\
CH 0.39 & $70.2317 \pm 3.04301$ \\
\hline
\end{tabular}

Table 2. Significance among groups of different calcium hydroxide concentrations.

\begin{tabular}{cccccccc}
\hline & \multicolumn{9}{c}{ CH Concentrations $(\boldsymbol{\mu g} / \mathbf{m L})$} \\
CH Concentrations & $\mathbf{2 5}$ & $\mathbf{1 2 . 5}$ & $\mathbf{6 . 2 5}$ & $\mathbf{3 . 1 2 5}$ & $\mathbf{1 . 5 6}$ & $\mathbf{0 . 7 8}$ & $\mathbf{0 . 3 9}$ \\
\hline $25 \mu \mathrm{g} / \mathrm{mL}$ & - & 0.523 & 0.445 & $0.001^{*}$ & $0.000^{*}$ & $0.000^{*}$ & $0.000^{*}$ \\
$12.5 \mu \mathrm{g} / \mathrm{mL}$ & 0.523 & - & 0.898 & $0.003^{*}$ & $0.002^{*}$ & $0.001^{*}$ & $0.001^{*}$ \\
$6.25 \mu \mathrm{g} / \mathrm{mL}$ & 0.445 & 0.898 & - & $0.004^{*}$ & $0.002^{*}$ & $0.002^{*}$ & $0.002^{*}$ \\
$3.125 \mu \mathrm{g} / \mathrm{mL}$ & $0.001^{*}$ & $0.003^{*}$ & $0.004^{*}$ & - & 0.807 & 0.747 & 0.714 \\
$1.56 \mu \mathrm{g} / \mathrm{mL}$ & $0.000^{*}$ & $0.002^{*}$ & $0.002^{*}$ & 0.807 & - & 0.938 & 0.902 \\
$0.78 \mu \mathrm{g} / \mathrm{mL}$ & $0.000^{*}$ & $0.001^{*}$ & $0.002^{*}$ & 0.747 & 0.938 & - & 0.964 \\
$0.39 \mu \mathrm{g} / \mathrm{mL}$ & $0.000^{*}$ & $0.001^{*}$ & $0.002^{*}$ & 0.714 & 0.902 & 0.964 & - \\
\hline
\end{tabular}

*Statistically significant.

\section{Discussion}

The interest in finding alternative sources of mesenchymal stem cells (MSC) and exploring its potential in dentistry is increasing. There are studies about other stem cell origins, such as human bone marrow mesenchymal stem cells, stem cells of the apical papillae, dental pulp stem cells, periodontal ligament stem cells, etc.. Still, little information was available regarding HUCMSC and its potential use in regeneration.

Although human bone marrow mesenchymal stem cells are more popular, there are disadvantages, such as the requirement of general anesthesia regarding the invasive surgical procedure involved, and multiple 
procedures may be needed to acquire a sufficient number of cells [10]. Human umbilical cord mesenchymal stem cells (HUCMSC) are used in this study because they can be isolated and expanded easily in large quantities in vitro [2].

Biocompatibility is an essential factor that must be contemplated when choosing a material for therapeutic purposes. In this study, HUCMSC were cultured in Minimum Essential Medium Alpha (MEM-A) added calcium hydroxide in normal culture condition, incubated at $37^{\circ} \mathrm{C}$ and $5 \% \mathrm{CO}_{2}$. We used MTT assay to determine cell viability and cytotoxicity under calcium hydroxide influence. HUCMSC is used instead of other cells because stem cells are different in their nature and character compared to other matured cells. Although in morphology HUCMSC is similar to fibroblast, HUCMSC has specific protein expressions that fibroblast doesn't have, such as the positivity of CD105, CD90, CD73, negativity of CD45 and CD34.

MTT assay is the most common method to determine cytotoxicity and proven to be more accurate and time-saving. The MTT assay principle is to break tetrazolium ring (3-(4,5-dimethylthiazole-2-yl)-2,5 diphenyl tetrazolium bromide) to produce insoluble blue-purple formazan product. The formazan production can be measured by optical density spectrophotometry. The lower the optical density means the lower living cells to metabolize the MTT. This study used 24-hour exposure of $\mathrm{CH}$, instead of lower exposure times to extrapolate that clinically $\mathrm{CH}$ was applied for long-term exposure.

Calcium hydroxide is chemically categorized as a strong alkali with a high pH (about 12.5-12.8) and its core effects originated from ionic separation of $\mathrm{Ca}^{++}$and $\mathrm{OH}^{-}$ions [3]. Calcium ion plays an important function in the intrinsic pathway of apoptosis. The upregulation of calcium into mitochondrion results in the release of cytochrome c. In cytoplasm, the cytochrome c binds to apoptotic protease-activating factor-1 (APAF-1), a cytoplasmic protein, and forms the apoptosome, which turns and activates procaspase-9 into caspase-9 and subsequently activates other caspases to carry out cell death [11]. Calcium hydroxide may possibly upregulate the expression of caspase-9, but further research is important to determine the effect of time and duration of calcium hydroxide application.

In this study, a significant decrease in cell viability might be caused by apoptosis. Apoptosis is a programmed cell death mechanism that engages in the homeostatic management of cell population, with no inflammatory reaction occurring [7]. Apoptosis is initiated by either an intrinsic or an extrinsic pathway.

Calcium hydroxide is well tolerated by bone and pulpal tissue. Some studies used a well-established cell line to assess CH's cytotoxicity, such as fibroblasts from various origins and reported good biocompatibility [12]. However, $\mathrm{CH}$ will create a zone of necrosis if in direct contact with tissue, altering the physicochemical form of cell to cell material through the break of glycoproteins, causing protein alteration [3]. This is in parallel with the result of this study, which found that calcium hydroxide affects the viability of HUCMSC.

\section{Conclusion}

These results show $\mathrm{CH}$ effects the viability of HUCMSC depending on the concentration used. This study provides evidence that $\mathrm{CH}$ can decrease the viability of HUCMSC on a longer period. The lower the concentration of Calcium hydroxide, the higher the viability of HUCMSC. Since this study is the first step of HUCMSC exploration on $\mathrm{CH}$, further studies will be required to reveal more novel mechanisms of HUCMSC for regenerative endodontic purposes.

\section{Authors' Contributions}




\begin{tabular}{|c|c|c|}
\hline EPP & (iD) $0000-0001-9962-235 \mathrm{X}$ & $\begin{array}{l}\text { Conceptualization, Methodology, Investigation, Formal Analysis, Writing - Original Draft } \\
\text { Preparation, Writing - Review and Editing, Project Administration and Funding Acquisition. }\end{array}$ \\
\hline IW & (iD) $0000-0002-5928-7005$ & Investigation, Resources, Supervision and Funding Acquisition. \\
\hline $\mathrm{FC}$ & (iD) $0000-0001-6363-8093$ & Methodology, Investigation, Resources and Project Administration. \\
\hline MK & (iD) $0000-0002-3869-754 \mathrm{X}$ & Methodology, Investigation, Resources, Writing-Original Draft and Project Administration. \\
\hline $\mathrm{NH}$ & (iD) $0000-0002-9261-3626$ & Methodology, Investigation, Resources, Project Administration and Supervision. \\
\hline NH & (iD) $0000-0003-0807-0081$ & Methodology, Investigation, Resources, Project Administration and Supervision. \\
\hline ERW & (iD) $0000-0002-9554-6051$ & Methodology, Writing - Original Draft Preparation, Writing-Review and Editing. \\
\hline APN & (iD) $0000-0001-7427-7561$ & Methodology, Writing - Original Draft Preparation, Writing - Review and Editing \\
\hline SG & (iD) $0000-0003-2398-0016$ & Writing - Original Draft Preparation, Writing - Review and Editing. \\
\hline HS & (iD) $0000-0002-3358-5231$ & Writing - Original Draft Preparation, Writing - Review and Editing. \\
\hline $\mathrm{EH}$ & (iD) $0000-0001-9723-8098$ & Methodology, Investigation, Formal Analysis, Software, Validation and Data Curation. \\
\hline FAR & (iD) $0000-0001-8182-1465$ & Methodology, Investigation, Resources and Project Administration. \\
\hline
\end{tabular}

\section{Financial Support}

Lembaga Pengelola Dana Pendidikan Kementerian Keuangan Republik Indonesia and Faculty of Dental Medicine, Universitas Airlangga, Surabaya, Indonesia (Grant No. 2134/2019).

\section{Conflict of Interest}

The authors declare no conflicts of interest.

\section{Acknowledgement}

The authors thank the Publication Center, Faculty of Dental Medicine for technical supports

\section{References}

[1] Meguid EA, Ke Y, Ji J, El-Hashash AHK. Stem cells applications in bone and tooth repair and regeneration: New insights, tools, and hopes. J Cell Physiol 2018; 233(3):1825-35. https://doi.org/10.1002/jcp.25940

[2] Li T, Xia M, Gao Y, Chen Y, Xu Y. Human umbilical cord mesenchymal stem cells: An overview of their potential in cell-based therapy. Expert Opin Biol Ther 2015; 15(9):1293-1306. https://doi.org/10.1517/14712598.2015.1051528

[3] Mohammadi Z, Dummer PMH. Properties and applications of calcium hydroxide in endodontics and dental traumatology. Int Endod J 201 1; 44(8):697-730. https://doi.org/10.1111/j.1365-2591.2011.01886.x

[4] Ba-Hattab R, Al-Jamie M, Aldreib H, Alessa L, Alonazi M. Calcium hydroxide in endodontics: an overview. Open J Stomatol 2016; 6(12):274-89. https://doi.org/10.4236/ojst.2016.612033

[5] Kahler B, Chugal N, Lin LM. Alkaline materials and regenerative endodontics: a review. Materials 2017; 10(12):1389. https://doi.org/10.3390/ma10121389

[6] Peters OA. Research that matters-biocompatibility and cytotoxicity screening. Int Endod J 2013; 46(3):195-7. https://doi.org/10.1111/iej.12047

[7] Collado-Gonzáles M, García-Bernal D, Oñate-Sánchez RE, Ortolani-Seltenerich PS, Álvarez-Muro T, Lozano A, et al. Cytotoxicity and bioactivity of various pulpotomy materials on stem cells from human exfoliated primary teeth. Int Endod J 2017; 50(Suppl2):e 19-e30. https://doi.org/10.1111/iej.12751

[8] Pires CW, Botton G, Cadoná FC, Machado AK, Azzolin VF, da Cruz IBM, et al. Induction of cytotoxicity, oxidative stress and genotoxicity by root filling pastes used in primary teeth. Int Endod J 2016; 49(8):737-45. https://doi.org/10.1111/iej.12502

[9] Hendrijantini N, Kresnoadi U, Salim S, Agustono B, Retnowati E, Syahrial I, et al. Study biocompatibility and osteogenic differentiation potential of human umbilical cord mesenchymal stem cells (hUCMSCs) with gelatin solvent. J Biom Sci Engineer 2015; 8(7):420-8. https://doi.org/10.4236/jbise.2015.87039

[10] Hendrijantini N. Comparative in vitro study of the cytotoxicity of gelatin and alginate to human umbilical cord mesenchymal stem cells. Dental J 2019; 52(1):36-40. https://doi.org/10.20473/j.djmkg.v52.i1.p36-40

[11] Kontogiannis TG, Tosios KI, Kerezoudis NP. Effect of calcium hydroxide as intracanal medicament on the expression of caspase-9 located within the radicular cyst epithelium. Aust Endod J 2019; 45(3):352-6. https://doi.org/10.1111/aej.12325

[12] Modena KCS, Casas-Apayco LC, Atta MT, Costa CAS, Hebling J, Sipert CR, et al. Cytotoxicity and biocompatibility of direct and indirect pulp capping materials. J Applied Oral Sci 2009; 17(6):544-54.

https://doi.org/10.1590/S1678-77572009000600002 